\title{
FROM KHILÂFAH TO MODERN STATE: The History of Islamic Political Transformation
}

\author{
Ahmad Khoirul Fata, ${ }^{*}$ Adnan, ${ }^{*}$ and Mahfud Fauzi, ${ }^{*}$ \\ * Institut Agama Islam Negeri Sultan Amai Gorontalo, Indonesia \\ ** Institut Darul Qur'an (IDAQU) Bogor, Indonesia \\ E-mail: cakfata@gmail.com
}

\section{Abstract}

This article discusses the dynamic and changes in Islamic political history. Rather than focuses on the Islamic doctrine, it focuses on the characteristics of each historical period. Through historical approach, this study reveals that Islam and state-politics are two sides of a coin. Since the beginning of Islam, it has been intertwined with state politics. Nevertheless, the history of Islamic politics has many faces. There is no standard shape or entity of Islamic politics. Changes and variation are the result of the Islamic ummah's efforts to develop political institutions that suit the demand of the era while trying to adhere to the Islamic teachings. This dynamic is seen in the changes from the era of the Prophet PBUH, the era of the four main Caliphs, up to the era of the large dynasties. In this modern era, the Islamic politics experiences a crisis due to the downfall of the old Islamic political entity (the caliphate) and the interaction with the modern west-political ideas. Various thoughts and political concepts tries to provide answers for the appropriate Islamic political shape/entity for this new era. However, currently a standard and ideal shape for an Islamic political entity is yet to be found.

Tulisan ini membahas dinamika dan perubahan yang terjadi dalam sejarah politik Islam. Kajian difokuskan pada karakteristik di tiap-tiap periode sejarah, bukan pada doktrin politik Islam. Dengan pendekatan kesejarahan kajian ini menunjukkan bahwa Islam dan politik-pemerintahan merupakan dua sisi mata uang yang tidak terpisahkan. Sejak awal mula Islam sudah 
berkelindan dengan urusan politik kenegaraan, dan tidak terpisah. Meski demikian, sejarah politik Islam menampilkan wajah yang beragam, tidak tunggal. Tidak ada bentuk lembaga politik Islam yang baku. Perubahan dan keragaman terjadi sebagai hasil dari upaya umat Islam membangun lembaga politik yang sesuai dengan tuntutan zaman tanpa menyalahi nilai-ajaran Islam. Dinamika itu terlihat dari perubahan yang terjadi pada era Nabi, empat khalifah utama, hingga era dinasti-dinasti besar. Di era modern, politik Islam mengalami krisis sebagai akibat dari kejatuhan lembaga politik Islam lama (khilâfah) dan persentuhan dengan ide-ide politik Barat modern. Di era ini muncul beragam pemikiran dan konsep politik yang mencoba menjawab bagaimana bentuk politik Islam yang tepat untuk zaman baru tersebut. Namun sayangnya, hingga kini belum ditemukan bentuk lembaga politik Islam yang baku dan ideal di zaman modern.

Keywords: Caliphate; Islamic politics; modern state; transformation

Received: March 23, 2021; Accepted: June 29, 2021

\section{Introduction}

Caliphate has currently become a hot issue. On one hand, there is a group that consider caliphate as the only political system that appropriates with Islam, and considers other state-political system as against Islam, kufr, and even considered as tâghht (earthly tyrannical powers that against the oneness of Allah) (Zallum 1995; Umam 2019). While on the other hand, there are also groups that are insisting on refuting the caliphate and considered the will to return to the caliphate time as a mere utopia. More than that, there are some of these groups overtly denounce the caliphate political system in Islam. These attitudes are parts of the dialectics of Islamic discourse and state/politics in modern era.

Discussion on the theme of the Islamic relation with the state is relevant and is still a hot issue. Whether Islam regulates the state-politics, or does Islam merely regulate things related to the worshipping and the relationship between God and mankind? If Islam does regulate the state-politic businesses, to what extent Islam manage this business? Such questions bombarded the modern Islamic political discourse and resulted in various groups providing their own answers and justifications.

Based on this background, it becomes interesting to discuss Islam and state-politics from the historical perspective. This historical perspective is 
intentionally proposed to study the dynamics of Islamic ummah within the process of shaping the political system that was considered as the most appropriate with the need of its time, by observing the Islamic teachings. Therefore, this article considered Islamic politics as an effort of the Islamic ummah to interpret the Islamic teachings into daily life to answer the challenges of their era. Islamic politics in this article is not viewed from doctrinal perspective. Nevertheless, the emphasis of this study is not on the stories of events during the Islamic political history, but rather on the characteristics of each historical period.

\section{Caliphate: the Old Islamic Political Institution}

From its early days, Islam has been intertwined with politics and power (Kalkan and Nar 2020). The teaching of the Prophet Muhammad PBUH did shake not only the theological believes of the Arabs but also shaken the long-maintained sociopolitical order of that time. This political dimension has become even stronger when the Prophet PBUH migrated to the Yatsrib city. His ability to create peace among the disputing groups in Yatsrib, and managing them into a new plural society, has made him both a spiritual and a political leader (Moten 1996, 21; Bawazir 2015, 11-14; Fares and Al-Tikriti 2018). To bind this newly formed society, the Prophet Muhammad PBUH, together with the groups of society in Yatsrib agreed on the new abiding rule called the Madinah Charter (Mîthâq al-Madinah). To signify the rise of this new era, the Prophet PBUH changes the name of the city into Madînat al-Nabî, or often called as Madinah/Medina (Ahmad 2014; Thaba 1996, 97-99; Kalkan and Nar 2020).

Abdul Aziz noted that even though Madinah in the time of the Prophet has created a leadership beyond blood and tribal bonds, it was yet proper to be called as a state. The newly achieved political power was just at the stage of chiefdom (imârah), that is power centralization and sociopolitical integration beyond the blood and kinship-based ties, as applied in a tribal political power. Aziz's conclusion is a form of simplification that viewed Madinah at the time of the prophet through a more advanced state concept, with its complex governance system as it is applicable today. At the same time, this conclusion could not neglect the fact that Islam is not free of political matters since its beginning (Aziz 2016, 369).

If viewed from the theories about the formation of the state, in fact, Madinah at that time had fulfilled the required elements as a state, such as 
territory, population, government, and sovereignty (Budiarjo 2013, 51). Moreover, Madinah also has its own constitution that regulates all elements in it and the Prophet as its leader also carries out diplomatic missions to various countries around. In relation with the power distribution and government bureaucracy applied at that time, they were adjusted to the need of each existing political power (Noer 2003, 125-6). Within this context, Patricia Crone sees the Muslim politics of this middle age as having distinctive characteristics that centered on the person, not the institution. Within such a society, there is an individual political authority obtained through non-formal way, but rather based on the individual aptitude and the military domination of the tribe. Such uniqueness is often misunderstood by the western people (Crone 2005, 3). The main problem in leadership succession of such political leadership is on, "who to become the leader?" and it is less about the form of the state or the governance system (Black 2011, 13).

This simple political institution in Madinah has kept evolving along with the expansion of Islamic power post the Prophet Muhammad's time with all its complexity. The immediate successors of the leadership following the passing of the Prophet were called the Caliphates/ khalifah al-Rasûl, or simply called the Caliph/khalifah. Khalifah means the successor or the representative. Khalifah al-Rasûl means the person that succeeded the Prophet position as the leader of the political community. These successors served as the community leaders, implement the sharia, preserve, and defend the purity of the religious doctrine (Moten 1996, 21; Watt 2003, 32-33; Lewis 1988, 43-44; Amsori and Ernawati 2019). Nevertheless, Moten insisted that the Caliphs were not the Prophet. They did not inherit the metaphysical distinction or theocratic distinction of the prophets, thus, the ummat only obeys the Caliphs as long as they adhere to Allah's way taught by His Prophet (Moten 1996, 92). Azra views the caliphates as "religion-politics organic system dominated by the relationship between the sacred and the politics" (Azra 2016, 27-28)

The term caliphate is considered similar to two other terms: imâm and amîr al-mu'minîn. In this case, Abû Zahrâ as cited by al-Damîjî described the term in an interesting light: "... it is called Caliphate as its responsibility as the highest leader to substitute the Prophet PBUH in managing the interests of the Muslim ummah. It is called 'imâm' as he must be obeyed by the ummah just like the congregation must obey the imam in prayer" 
(al-Damîjî 1408 H, 33-35). Meanwhile, the term Amîr al-Mu'minin was introduced during the term of the second caliph, 'Umar ibn al-Khattâb. Following the demise of the first caliph, Abû Bakar, 'Umar ibn al-Khațâb was appointed as the second caliph, with the title of khalifah khalifah al-rasûl, the substitute/replacement of the prophet. This title was considered too long, and will be even longer in the later days, therefore 'Umar agreed to title of Amîr al-Mu'minin for himself. In the later days, this early Islamic leadership is considered as the prototype for the Islamic politics. Many scholars and Islamic political movement in modern era identify their ideas and political dreams to this era.

During the Prophet time, the main characteristic of leadership and the four main caliphs was egalitarianism with high regard on deliberation (Moten 1996, 90-92). The inexistence of complex and multilevel power structure had strengthened this character. The caliph was the main actor. In many decision-makings they invited the important figures to deliberate. Deliberation and consultation were evident in the shifting of leadership from one caliph to his successor. From the election of the four main caliphs, Moten simplified the succession into two stages: 1. Consultation, nomination, and election by the representatives of the ummat (al-bay'ah al-khâssah), and the next stage is; 2 . Confirming the elected caliph to the ummat through al-bay'ah alâmmah. In similar tones, Azra revealed that there were two key concepts in Islamic leadership post-prophet time, namely ikhtiyâr and bay'ah. The leaders that succeeded the Prophet Muhammad PBUH shall be elected from among his companions (ikhtiyâr), and following this election, they should be inaugurated by the oath of allegiance by the ummah (bay'ah) (Azra 2016, 25).

The idea on government led by a Caliph is called Caliphate/khilâfahconsidered as something of a fixture of Islamic government concept. The leadership after these four main Caliphs time (al-khulafâ' al-râshidûn) had continued on using the title of Caliph - and its government institution is called Caliphate/khilâfah- regardless to having different system and character from the previous caliphate (Mubarok as cited in Aziz 2016, XVI). The adaptation of this monarch system had made the selection of a leader after the four main caliphs to no longer based on the shûrâ, but rather based on heredity. The leader also had absolute power. This change had happened since the First Umayyads Dynasty I $(661-750 \mathrm{M})$ in Damascus, to the Abbasids Dynasty (750-1258 M) in Baghdad, the Second Umayyads Dynasty 
(756-1031 M) in Cordoba, up to the Ottoman Dynasty (1299-1923 M) in Anatolia. Moten pejoratively wrote: "the Caliphate had been changed into a mulk (monarchy), a change from siyâsah dîniyyah to siyâsah 'aqliyyah with the support of the "așâbiyyah in seizing power" (Moten 1996, 93).

The emphasis on the figure rather on the institution, as described by Crone above, made the Middle Ages Muslim thinkers and Muslim political theorist largely discussed leadership rather than state institution. There almost no discussion on the current form of state and government system. Their writings emphasize the urgency, requirements, objectives, or the rights-duties of the leader (Aziz 2016, 16-17). The important point was the objective of the establishment of a state that is to protect the religion, and to bring about justice and people's welfare, and to make sharia as the only standard that should be implemented in lives (Rosenthal 1962, 22; Fata 2012).

Thus, the state and its government system were wasilat (means/tools) to achieve those objectives, and not the objective (ghâyah) itself (Muhajir 2017, 23). For many Muslim thinkers at that time, as long as the leader preserve and protect the religion and implement the sharia, the type of the state and the succession of the leadership were of no importance. This doctrine was religiously followed by the majority of the thinkers and the community at that time (Lambton 1991, 19). This mainstream group was known as Ahl al-Sunnah wa al-Jamâ'ah (Sunnah/Sunnî). For the Sunnî, the acceptance on the type of the state and any agreed government system were the logical consequence of the inexistence of the definite leader appointed by the Prophet Muhammad PBUH. Following the passing of the Prophet, the ummah had opportunity to manage their own political matters. Hence, they developed the concept of $i j m \hat{a}^{\prime}$ (the consensus of the ummah or ulama) as the basis of its legitimation (Lambton 1991, 41; Kamil 2013, 8; Hazleton 2009, 61).

Acceptance toward the monarch in the old era was an understandable thing considering this system was closer to their daily lives at that time. In the history of the old Arabs, probably it was only at the time of the prophet and the four caliphs that they interacted with the non-monarchical political system (Madjid 1998, 188-9). They only knew and came into contact with simple kinship gathering or communal leadership, and large states with the monarchical system. Rosenthal argued that only force that was able to unite those different kinship-based socio-political organizations. This short 
acquaintance did not equip them with cultural and institutional readiness to carry out this system into the next eras. When the caliphate area had begun to expand into Sassania (Persia) and Byzantium who were more progressed in terms of government bureaucracy, the adaptation process of a more mature government system happened. Many experts were needed to fill in the government organization, and those were filled by the experts from Persia and Byzantium. The Arabs at that time, had yet sufficient experience in complicated government bureaucracy. Hence, the Muslim leader has to accommodate the adoption of this more modern government management system, regardless to the highest leader (caliph) should always belong to the Arabs (Rosenthal 1962, 21).

It does not mean that during this time there were no alternative political ideas. Political philosophers such as, al-Farâbî had tried to develop ideas on ideal political system. However, his ideas had no empirical background and even tend to be utopic, hence, hard to be implemented. This ideal state idea of al-Farâbî rely heavily on the figure of ideal leader of king-philosophy (Sjadzali 1993, 49-57; Rosenthal 1962, 132; Mohamad, Faeghe, and Jangjooi 2017). Previously, a political idea was different from the mainstream (Sunnî) that tend to be accommodating (Cepoi 2013). The Khawârij group that was formed after the tahkîm between 'Alî ibn Abî Tâlib and Mu'âwiyah, was considered by many scholars to have more progressive and more democratic ideas at that time. Theoretically, the basis of the Khawârij movement was lâ hukm illâ Allâh, there is no decision but Allah's. Through this guideline, the Khawârij stated that each poltical decision should be based on the commandment of Allah (Watt 2003, 54; Zubaidah and Zulkifli 2016).

Lambton noted that at least three things that differentiate the Khawârij from the mainstream group. First, they denounce the leadership restriction only to the descendants of the Quraysh as decided by the Sunnî group. For the Khawârij, leadership should not only came from certain family or tribe. Everyone in Islam would have a right to be a leader, even if he was a slave. The only requirement by the Khawârij for a leader is that "He should be a good Muslim and keep being a good Muslim leader." Second, the existence of imam is not an absolute necessity for a community. Third, their strong attitude in implementing the duties for Muslim individuals. Each Muslim, even though he is an Imam, was required to implement religious obligations. The violation against this was considered 
as paganism with the consequence of deserving the death penalty (Lambton 1991, 23-24).

Apart from the Khawârij, there was also the Mu'tazila. For this rationalist group, the main requirement for an imam is justice. The importance of this just attitude has made them obliged the people to overthrow the unjust leader, even if it should be carried out through the means of violence. It must be noted that the justice here, refers to the theology of Mu'tazila. About the requirement of a Quraysh as an imam, initially, Mu'tazila did not limit the leadership only on the Quraysh, however, later, they prohibited non-Quraysh to be a leader if there was still a Quraysh among them that was considered as suitable to be the leader. Like the Khawârij, Mu'tazila also considered leadership as non-mandatory. For them, an ideal community is a just community, even though this can be achieved without the existence of the leader (Lambton 1991, 37-38; Aydinli 2010).

Shî'a, deviates from this view, and bring about a theological-mythical political view. The belief of the Shî‘a Imâmiyyah is based on two main sources: first, mythical speculation from the eastern Hellenism added with metaphysical ideas and doctrines about fate. For them, the divine light (Nûr Muhammad) has manifested in a selected person for each generation, that is in 'Alî ibn Abî Tâlib and each imam of his descendants. With this divine light, they obtained sacred knowledge (hikmah) that freed them from sin. The second doctrine of the Shî́a was the Mu'tazila doctrine that justice (al-'adl) is an inherent quality of God and that goodness-badness are rational (Lambton 1991, 221).

The initial difference between Shî'a and Sunnî was on the theme of who deserved to be a leader to succeed the Prophet Muhammad PBUH. For the Shî‘a, imâmah (leadership) is part of the usûl aldîn. The imâm was not selected by the people. He was the result of the Prophet Muhammad's appointment and the testament of the previous Imâms. Shî‘a claimed that 'Alî had been appointed by the Prophet to succeed him. This was announced by the Prophet himself in front of many people in a place called Ghadîr Khum, however, 'Alî ibn Abî Ṭâlib's right was later "robbed” by the first three Caliphs (Fata 2017; Washil and Fata 2018). The Shî'a considered that the right to the imâmat did not only belong to Ali but also to his descendants. Nevertheless, some groups have different views on who among Ali's descendants deserve to be the imâm among Shî‘a themselves. These 
differences in determining who the most appropriate imâm was especially after the demise of the third imâm, Husayn ibn 'Alî ibn Abî Tâlib.

The Shî‘a Khaysaniyah viewed that the most appropriate imâm to replace the third imâm was Muhammad ibn Hanafiyyah, 'Alî's son from another wife (not from Fâtimah, the Prophet's daughter). However, most Shî'a believed that only 'Alî's sons from Fâtimah who have the rights to the imâmat. This majority of the Shî‘a agreed to appoint 'Alî Zayn al-Âbidîn as the fourth imâm. Following the demise of this fourth imâm, this majority of the Shî'a was on disputes about who deserve to succeed 'Alî Zayn al-Âbidîn as an imâm. There was a Zaydiyah with Zayd as their fifth imâm. Another group elected Abû Ja'far Muhammad al-Bâqir as the fifth imâm and then elected Abû 'Abd Allâh Ja'far Șâdiq as the sixth imâm. Following the demise of Ja'far Șâdiq, his followers acknowledged Ismail as the seventh imâm. This group is later known as the Shî‘a Ismailiyyah or Sab 'íyyah due to their belief only on seven imâms, with Ismail as the last imâm. Other group elected Mûsâ al-Kâzim as the seventh imâm and his successor was 'Alî al-Riḍ̂a, Muhammad ibn 'Alî al-Riḍâ, Alî al-Hâdî, Hasan al-'Askarî, and the last imâm was Muhammad al-Mahdî ibn Hạan al-Askarî. This last imâm was believed to have vanished (ghâyb). However, they still can communicate with the imâm through a medium (nuwwâb, sufarâ') (Lambton 1991, 222; Sjadzali 1993, 211-3; Fata 2017). In the belief of the Imâmiyyah, the imâms were holy, as they have the characteristic of 'ismah (free from sin) and they have the lutf (generosity/tenderness) characters compared to other human. Therefore, the authority of the imâm encompases all aspects of religion (Fata 2017).

Watt argued that the emergence of the Shî́a and the Khawârij was a different response toward the same situation, the transformation of the nomadic Arabs into elite military of an imperium. When the Shî‘a group felt insecure, they sought the safety on the charismatic leader, considering they rooted on the idea that the God's Kingdom from the Southern Arab region. Similarly, the Khawârij also felt insecure and seek refuge on the charismatic group, as many of the Khawârij leaders were from the tribes in the Northern Arabs who have no experience on the God's kingdom, but highly respected tribalism (Watt 2003, 56).

Some scholars considered the beginning of the shift of Islamic political focus in the middle ages, initially it emphasized on caliphate as the center of legitimation, it shifted to the ummat as the center, whereas caliphate or wilâyat (political authority) was merely an instrument. In this 
case, Sahal named Ibn Taymiyyah as the middle age Muslim scholar who signify the shift of this paradigm. It was due to the Ibn Taymiyyah framework who emphasized on sharia as the main locus of Islamic politics. At the same time, sharia was the domain of the ulama', and not the leader. Even, at that time, many of the ulama' was outside the government and their legitimation did not come from the leader (Sahal as cited in Hidayat [ed.] 2014, 61-62).

The long winding road of the caliphate with all of its intellectual and political dynamics have established this system into the collective memory of the Islamic ummat. It became an inseparable part of the Islamic civilization. Although its ability to survive for centuries made it almost irreplaceable, the Islamic ummat in the past had almost never thought of replacing it with other models. Even today, many of the ummat idealized this leadership concept. Thus, it is understandable that there was a huge shock when the Islamic ummat was up against the different and modern political ideas of the west. The turbulence became even stronger along with the degradation of the Islamic ummat's economy and politics and the trauma due to colonization.

\section{Islamic Political Turmoil in Modern Era}

Azyumardi Azra saw the modern era or the contemporary era as the time of the most severe crisis in Islamic civilization history. In addition to the unhealthy ummah condition, this crisis was also due to the clash against the West, which has caused the Islamic ummah to fall into imperialism and colonialism. The impact of this crisis was the identity crisis among the Islamic ummah (Azra 2016, 23-24). This condition - worsened by the progress of the West in science and knowledge, technology, and organization - had lent a hand to the emergence of contemporary Islamic political thoughts at the end of the XIX century (Sjadzali 1993, 115).

The west introduced their civilization all over the world through globalization and colonialization. Ejaz Akram defined globalization as intensification of human condition to be modern. Its objective was homogenization of different traditions and cultures all over the world, and western hegemony. Globalization had caused systematical damage to the traditional institutions in non-Europe countries (Akram as cited in Lumbard 2004, 241). This process was carried out through political and military colonization, then through ideology and culture (Naeem as cited in Lumbard 2004, 80). Tibbi, insisted that this process had caused an 
everlasting wound for the Islamic ummah, which later articulated through various political actions and violence as a defensive-cultural response (Tibbi 2009, 35).

Tibbi wrote that modernity had two different dimensions, cultural and institutional. Modernity culture, also called 'subjectivity principle', was based on several main events in European history such as Renaissance, Reformation, Enlightenment, and French Revolution. This dimension is strongly related to the world view that had uplifted the West into a higher civilization, where human is the center, and not god. On the other hand, the institutional dimension was closely tied with power (Tibbi 2009, 34-37). In the first dimension, modernism, as Naeem viewed, was a rebellion against religion in all aspects of life, thus, the West shifted from the deeply Christian civilization in the middle ages into secular humanistic in modern era (Naeem as cited in Lumbard 2004, 80).

This modern western civilization was considered unfamiliar and has no historical root for the Islamic ummat. Azra described that the Islamic ummat had long been familiar with the concept of dâr al-Islâm and dâr al-harb, however, was later confused with the concept of nation state from the West (Azra 2016, 33). Akram considered this an unacquainted concept had destroyed the traditional political institutional order, had destroyed the unity of the ummat, and had caused the desacralization and demoralized the political process, evolution toward the state country that threaten the security of the Islamic world, and the emergence of democracy concept in Islamic world (Akram 2004, 243).

In its defensive situation, political power in Islam was forced to make many changes. Since 1730s, the Ottoman carried out changes in its military and administration systems by adopting those of the European countries systems. These changes were continued to be carried out and expanded into regional political system, trade system, and diplomacy (Azra 2016, 34; Mohammed 2018). Up to the time where government administrational changes were not the only changes happened, but also the caliphate system of the Ottoman was shifted into a modern secular Turkish Republic. This change was due to the raise of nationalism among the plural Ottoman people, especially among the Turks and the Arabs themselves. George Antonius wrote that the Arab nationalism movement was started in Beirut in 1875 through a secret organization. However, the most evident statement on Arabs' nationalism was on Abdurrahman al-Kawâkibî writings published 
in Egypt between 1898 up to his death in 1902 (Antonius as cited in Watt 2003, 117).

By referring to Shlomo Avineri, Abdul Aziz noted down two sources of Arabs nationalism, the Christian Arabs intellectual and the Orthodox Greeks who were educated in schools established by Presbyterian missionaries from the US in Beirut. One of the most prominent figures of this group was Butrus Bustani. In 1985 he established Majma' Tahzîb, an Arabic literary study center where all of its members were Christians. In the same year, he also established a Madrasah Wataniyyah. In 1866, he became the founder of Syrian Protestant College who was the pioneer of the American University in Beirut (Aziz 2016, 94-95).

The second path was from Egypt. Egyptian nationalism was territorial and centered on the identity as Egyptian. Egypt modernization was pioneered by Muhammad Ali Pasha (1765-1848) through the establishments of modern schools such as technical school in 1816, and medical school in 1827, and agricultural school in 1836. These schools played an important role in the emergence of the spirit of Egyptian as a country. The students from Egypt were sent to Europe also contributed to strengthen this spirit. In developing their nationalism, the Egyptians referred to the roots of the pre-Islamic civilization. The Egyptian nationalism gained its strengthening momentum in 1915, where in negotiation before the Arabs were involved in the First World War, the Makkah Sharif, who was positioned as the speaker for the Arabs, called the Red Sea as the west territorial boundary for the Arabs. It was similar to calling Egypt as not part of the Arab nations, while they talk in Arabic and for a long time have acknowledged themselves as the descendants of the Arabs (Aziz 2016, 95; Watt 2003, 117).

The Arabic figure that was considered to have significantly contributed to the strengthening of the Arab nationalism was al-Kawâkibî (1848-1902). This Syrian thinker who resided in Egypt refuted the authenticity of the Turks as the Islamic ruler. He considered the Arabs as more appropriate to become the ruler as they represented the purity of Islam (Aziz 2016, 96). Al-Kawâkibî criticized the Ottoman government as tyrant who was not able to revive the Islamic teaching and had rather caused the decline of Islam. He argued that Islamic revival could not be achieved if the Turks do not return the ruling power to the Arabs. Al-Kawâkibî even accused the Turks to have seized the ruling rights of the Arabs, as according to the Sunni's doctrine, one of the requirements to become a caliph is the 
descendant of the Arabs/Quraysh. Therefore, al-Kawâkibî pointed out several advantages of the Arabs compared to other nations. Even though Azra viewed that al-Kawâkibî had yet to present a clear definition on "the Arabs nations," however, in later days, his ideas on Arabism was strengthened by the Christian-Arabs thinker, Negib Azoury (d.1906) by stating that the boundaries of the Arab Empire were: Efrat and Tigris valley, Indian Ocean, Suez Canal, and Middle Sea (Azra 2016, 56-57; Robby 2020, 1-32).

The idea of Arabs nationalism was not singular. The Christian Arabs nationalists, which several Muslim Arabs thinkers supported, formulated secular Arabism by referring to the grandness of pre-Islamic civilization. Whereas, majority of Muslim Arabs nationalists kept Islam as the basis of their nationalism ideology. The Arabism spirit had emerged due to the response of the Turkism spirit at that time. Two Turks nationalists' thinkers at that time were Namik Kemal (d. 1888) and Zia Gokalp (1876-1924). The reformation of government administration and military systems in Turk since the $18^{\text {th }}$ century was actually headed toward westernization. This program created the identity of Turks. Intensification of studies and literature on pre-Islamic Turks civilization and the decision to make Turkish language as the official language of the state in $1876 \mathrm{had}$ made the Turks nationalism even more mature. The Turks nationalism had found it shape following the defeat of the Ottoman in the WW I. As the consequence of this war, the Ottoman lost some of its territory was seized by the Europe. Almost similar to the Arabs nationalism, the Turks nationalism also took secular path as its choice. The dissolvement of the caliphate government and replaced by the Turks Republic in 1924 by Kemal Attaturk signify this secular choice (Azra 2016, 35-38; Aziz 2016, 95-96).

The idea on political reformation was also hand in hand with the reformation in religious side. In this sense, three leading figures in Islamic reformation - Jamâl al-Dîn al-Afghanî, Muhammad Abduh, and Rashîd Riḍa - played an important role. These three figures as the motors of the new Salafism with the main idea of one Islamic political tie in the form of Pan-Islamism. Even if they have differences in formulating the idea of Pan-Islamism, in general they have two common objectives: opposing the despotic government and encouraging the establishment of government that based on the deliberation as taught by the Prophet PBUH; and opposing the colonialism and western domination (Mujâhid 1954, 130-1; Sjadzali 1993, 125-6). 


\section{Modern Islamic Political Transformation}

The worsening internal Ottoman condition, their defeat in WW I, and the strengthening of nationalism among its people, made the Pan-Islamism idea hard to be realized. The Ottoman caliphate was ended with the establishment of the modern Turkish Republic. Enayat wrote that the process of eradicating the caliphate was carried out through two stages. The first stage was in 1922 when the Grand National Assembly had separated the sultanate position with the caliphate, where the caliph was made as a symbol of the whole Islamic spiritual leadership. The second process happened when the Ottoman caliphate was formally dissolved and replaced with a republic state (Enayat 2001, 79-82). Following the dissolvement of this caliphate, there were several attempts to reestablish a new Islamic political power (caliphate). These efforts were carried out in several Caliphate Congresses involving Islamic figures from all over the world. However, it failed. The dream to revitalize caliphate state in modern era was not carried out (Suminto 1985; Kramer 1986).

The longing for an Islamic political system and institution will be forever coveted by several Islamic groups while at the same time resisting the new political system from the west. One of these groups is the Hizbut Tahrir (HT) who has insistently refused democracy as it is considered incompatible with the Islamic teaching. The main difference between democracy and Islamic teaching relies on the concept of people sovereignty as the core of democracy. Al-Nabhani argued that democracy is an ideology (al-mabda') which believes that human themselves are entitled to established rules, as human being is considered as the source of power. Whereas, he argued, that sovereignty in Islamic governance lays on the sharia made directly by Allah (al-Nabhani 2001, 27). The obligation of the ruler is to ensure the sharia law, as he was sworn based on the Quran and the sunnah, and not to fulfil the willingness of the majority (Zallum 2002, 34). Zallum emphasized that the placement of people as the source of power theologically contradict the Islamic faith (Zallum 1995). Therefore, democracy is considered a kufr system. Thus, the Islamic ummat is forbidden/haram to adopt, follow, implement, and spread it. As the difference between Islam and democracy lays on its principle, they refused the effort to synthesize these two concepts into a form of "Islamic Republic" such as in Pakistan or Iran. To replace democracy, they proposed the concept of "caliphate/khilâfah" as the only government system that is in accordance with Islam (Zallum 2002, 29). 
In similar tone with HT, the people's position as the source of power became the main reason for Salafi group to refute democracy (almanhaj.or.id 2017; Wahid 2014). Salafi viewed the making of the law as the authority of Allah SWT and not people's authority. Therefore, the Islamic ummat was obliged to adhere this law established by Allah through the revelation to His Prophet. This provision is absolute. Adhering to the Allah will made the person who commit it as kafir or mushrik as they are considered to have followed the tâgût. Abû Muhammad al-Maqdisî viewed people's power in shaping and determining the law in a democratic system as a characteristic of the non-believer, polytheism, and lies that are contradictory with Islam. The obedience toward the law is one of worshipping forms that should only be offered to Allah (al-Maqdisî 2012, 8-11).

Maqdisî provided three main reasons why democracy is contradictory with Islam. First, people's legislation is not Allah's legislation. Meanwhile, Allah has sent His messenger to adhere only the Law sent by Him. Second, the legal source in democratic state was constitution based on the interest of the majority and not the Allah's law and the hadiths. In a democratic state, it is not possible to create a legislation taken from the Quran and the Hadiths if it is not in accordance with the state's constitution. In this point, al-Maqdisî saw that within democracy, the constitution is higher and more sacred than the Quran and the hadith. Third, democracy is the product of secularism. The freedom principle within democracy is free from religion and Allah's rules. Therefore, he firmly stated that democracy is a separate religion that is different from Allah's religion (Islam) (al-Maqdisî 2012, 27-32).

Fauzi M Najjar acknowledged the incompatibility between Islam and modern democracy. He described that the differences between the two lays on the fact that in Islamic theory of statehood, there is no difference between religion and society on the one hand, and between community and the state on the other hand. It was surely different from the theory of democracy - especially in the US and the UK. They strictly divided between community as a conglomeration of voluntary associations and the state as an agent that encourages partnership and spontaneous initiative among these associations. The function of the state in modern democracy is to preserve individual rights and promote human freedom, and it does not serve as the exponent of religion or ideology (Najjar 1958). 
Najjar explained that in democratic state, the differences and opposition are highly appreciated and preserved. It was different from the theocratic system that considers opposition as deviation. Further, he explained that democratic system that divided power into judicial, executive, and legislative institutions (trias politica) is an effort to prevent tyranny. Meanwhile, in Islam, the function of these three institutions lays on one agency/institution. Modern democracy was also established above the doctrine of human equality and individual's dignity. These basic rights were later brought about the consequence of election rights and the logic of people-based power. Najjar considered the people's power in democracy as equal to the God's power and sacred text in Islam. Another differentiating aspect was the separation between the state and the religion within the democracy system. In account of these differences, Najjar then concluded that Islam only has a few similarities with democracy. He was not even convinced that Islamic world would be democratic unless fundamental changes on its principles were carried out (Najjar 1958, 174-5).

Nevertheless, during that heated momentum, a transformation on modern Islamic politic happened through the introduction of the "Islamic state" concept as an alternative for the Caliphate state. According to Enayat, this concept has been introduced by modern Islamic political thinkers, both from the secular and Muslim thinkers. The combinations of various events that happened that time had made this concept quickly penetrated the center of modern Islamic religion-politics. The response of the traditionalists toward secularism in Turkey, and the crisis in the Palestine were factors that accelerated the acceptance of this concept. The figure who is considered to be the early theorist of the Islamic state in the modern era is Rashîd Ridâa (d.1935). The idea of the disciple of Muhammad Abduh was followed and developed by the fundamentalist groups. The involvement of these fundamentalists had made this initially vague concept clearer (Enayat 2001, 104).

Riḍa performed a soft transition from a caliphate into Islamic state. He used the net term that was not familiar in modern world and there was a sense of paradox in it, where al-dawlah or al-hukûmah al-Islâmiyyah. In the previous eras, the term khilâfah or imâmah was used to refer to the state or government. Later, the term imârah or wilâyah was used. Nevertheless, there was an ambiguity in Ridâ, where he repeatedly used the term al-khilâfah al-islâmiyyah or hukumah al-khilâfah. Enayat explained that the reason for this was because Riḍa was trying to reorganize the caliphate. Still at the same 
time he also wanted a new entity that institutionally and functionally had never existed before (Enayat 2001, 114). In other words, Riḍ̂’'s idea arose among the "tension between the demand of nationalism and the loyalty toward the caliphate in the beginning of the 1920s decade" (Haddad 1997, 253; Toure, Sahid, and Yabi 2018).

Riḍa had two objective: the people's sovereignty principle and possibility to create a man-made law. The first objective can be achieved through the shur â principle between the ruler and his people, through regulations made by legal scholars to avoid injustice. In addition, the ulama power was ideally placed as representation of the people. Meanwhile, the second objective was achieved through ijtihad. Rị̣a viewed Islamic reformation as does not necessarily mean to totally refer to the sources of Islamic law. However, to refer to the elements of early Islam idealism that was pure from the worldly intention, ethnicity prejudice, and sectarianism. The political, social, and economical matters of a state is regulated by the constitution that was inspired from the general principle of the Quran and the hadith, and the historical experience of the four first caliphs. In this area, Ridâ placed sharia as an entity that has authority to overrule the qanûn (positive law). When there was a conflict between the qanun and the sharia, the sharia will be won as qanun was a subordinate to the sharia. Therefore, the positive law can be accepted by Ridâ, however, it should adhere to the Islamic principles (Enayat 2001, 115-21).

Changes also happened on the political thought of the Shî́a. The effort to bridge Islam and modern political ideas have created the concept of wilâyah al-faqîh which was historically established in form of the Islamic Republic of Iran. In general, this concept has many similarities to the ideas of Rida, a modern democratic state, who kept the Ulama in their authoritative position, and made sharia as the standard reference for positive law (Anis 2013).

\section{Conclusion}

The interaction between Islam and politic has happened since the early days of Islam, and it has been going on as it is today. Both concepts interacted to create an interesting dynamic along the history of each era. Implementing Islamic teachings in different situations has raised diverse expression of the ummat in relation to government politics. This diverse expression had given multiple facets of the Islamic politics, and there was 
no single fix pattern on Islamic politics as believed by some groups of people. Historically, the Islamic politics appear to be dynamic and colorful. Within such context, Islamic politics since the time of the Prophet up to the caliphate era had provided a description on a system that centered on its leader. This situation changes when the old politics (caliphate) underwent a crisis and was overthrown in the early part of the twentieth century. The Islamic ummat had started to interact with western political ideas who is totally different from the old Islamic politics. This crisis and upheaval have encouraged the Islamic thinkers to formulate a new modern political institution that adhere to the Islamic values. Various new theories emerged and colored the modern Islamic politics. Today, this dynamic is yet to find its fix pattern and is yet able to become a model of modern Islamic politics.

\section{References}

Ahmad, Zainal Abidin. 2014. Piagam Madinah: Konstitusi Tertulis Pertama di Dunia. Jakarta: Al-Kautsar.

Akram, Ejaz. 2004. "The Muslim World and Globalization: Modernity and the Roots of Conflict." In Joseph EB Lumbard. Islam, Fundamentalism, and the Betrayal of Tradition. Indiana: World Wisdom.

Amsori and Ernawati. 2019. "Khilafah Islamiah in International Islamic Political Perspective.” ICIIS 2019, 7th-8th Nov., Jakarta, Indonesia. DOI: http://dx.doi.org/10.4108/eai.7-11-2019.2294582.

Anis, Muhammad. 2013. Islam dan Demokrasi: Perspektif Wilayah al-Faqih. Jakarta: Mizan Publika.

Arnold, Sir Thomas W. 1965. The Caliphate. London: Routledge \& Kegan Paul LTD.

Aydinli, Osman. 2010. "Mu'tazila's Imamah Theory: Theory and Practice." Dini Araştırmalar 3(7): 17-52.

Aziz, Abdul. 2016. Chiefdom Madinah: Kerucut Kekuasaan pada Zaman Awal Islam. Tangerang Selatan: Alvabet.

Azra, Azyumardi. 2016. Transformasi Politik Islam: Radikalisme, Khilafatisme, dan Demokrasi. Jakarta: Kencana.

Bakar, Abdullah Abu and Rafiullah Qureshi. 2020. "Civic Rights in Charter of Madinah and International Human Rights Conventions: 
A Comparative Study." Al-Milal: Journal of Religion and Thought 2(2): 196-211.

DOI: https://doi.org/10.46600/almilal.v2i2.153.

Bawazir, Tohir. 2015. Jalan Tengah Demokrasi: Antara Fundamentalisme dan Sekularisme. Jakarta: Pustaka al-Kautsar.

Black, Anthony. 2011. The History of Islamic Political Thought: From the Prophet to the Present. Edinburgh: Edinburgh University Press.

Budiarjo, Miriam. 2013. Dasar-dasar Ilmu Politik. Jakarta: Gramedia.

Cepoi, Ecaterina. 2013. "The Problem of Supreme Leadership ('Imâmah) in Sunni Political Thought." International Journal on Humanistic Ideology 6(1): $129-52$.

Crone, Patricia. 2005. Medieval Islamic Political Thought. Edinburgh: Edinburgh University Press.

al-Damîjî̀, 'Abd Allâh ibn 'Umar ibn Sulaymân. 1408 H. Al-Imâmah al-Użmâ 'Inda Ahl al-Sunnah wa al-Jamâ'ah. Riyâḍ: Dâr Tayyibah.

Enayat, Hamid. 2001. Modern Islamic Political Thought. Kuala Lumpur: Islamic Book Trust.

Farahati, Abbasali. 2011. "The Mosque as the First Political-Ideological Base in the Islamic Society." Journal of Politics and Law 4(1): 146-52.

DOI: $10.5539 /$ jpl.v4n1p146.

Fares, Mahmoud Turki and Suhad Fadel Abbas Al-Tikriti. 2018. "Khilafah Foundation in the Islamic Arab State." Journal of Tikrit University for Humanity 25(9): 158-82.

Fata, Ahmad Khoirul. 2012. "Kepemimpinan dalam Perspektif Pemikiran Politik Islam." Jurnal Review Politik 2(1): 1-15.

DOI: https://doi.org/10.15642/jrp.v2i1.1001.

Fata, Ahmad Khoirul. 2017. "Hadits Ghadir Khum: Mandat Kepemimpinan untuk Ali?.” Jurnal Studi Islam 2(3): 71-90.

Haddad, Mahmood. 1997. "Arab Religious Nationalism in The Colonial Era: Rereading Rashid Rida's Ideas on The Caliphate." Journal of the American Oriental Society 117(2): 253-77.

DOI: https://doi.org/10.2307/605489. 
Hazleton, Lesley. 2009. After The Prophet: The Epic Story of the Shia-Sunni Split. New York: Anchor Book.

Kalkan, Nurettin and Maşallah Nar. 2020. "The Concept of Islamic State through Prophet Muhammad's Political Experience." Uluslararast Medeniyet Çalışmaları Dergisi 5(2): 182-98.

Kamil, Sukron. 2013. Pemikiran Politik Islam Tematik. Jakarta: Kencana.

Kramer, Martin. 1986. Islam Assembled: The Advent of the Muslim Congresses. New York: Columbia University Press.

Lambton, Ann K.S. 1991. State and Government in Medieval Islam: an Introduction to the Study of Islamic Political Theory: The Jurists. New York: Routledge Curzon.

Lewis, Bernard. 1988. The Political Language of Islam. Chicago \& London: The University of Chicago Press.

Lubis, Amany Burhanuddin Umar. 2002. "Sistem Politik Dinasti Mamluk: Suatu Kajian Sejarah.” Dissertation, IAIN Syarif Hidayatullah Jakarta.

Madjid, Nurcholish. 1998. Islam: Doktrin dan Peradaban. Jakarta: Paramadina.

al-Maqdisî, Abû Muhammad. 2012. Democracy: A Religion!. Australia: al-Furqan Islamic Information Centre.

Moaddel, Mansoor. 2002. "The Study of Islamic Culture and Politics: An Overview and Assessment." Annual Review of Sociology 28: 359-86.

DOI: https://doi.org/10.1146/annurev.soc.28.110601.140928.

Mohamad, Rezamojtehed Chalabi Faeghe, and Kharata Farzad Jangjooi. 2017. "An Analysis of Cardinal Concepts in Farabi's Political Thought." International Journal of Research in Social Sciences 7(9): 263-78.

Mohammed, Ibtsim Hmood Mohammed. 2018. "The System of Governance and Administration in The Ottoman Empire (The Sultan, The Great Sadr, Sheikh Islam).” Journal of Tikrit University for Humanities 25(9): 139-57.

Moten, Abdul Rashid. 1996. Political Science: an Islamic Perspective. London: MacMillan Press. 
Moudden, Abderrahmane El. 1995. "The Idea of the Caliphate between Moroccans and Ottomans: Political and Symbolic Stakesin the 16th and 17th Century-Maghrib." Studia Islamica 8: 103-12.

DOI: https://doi.org/10.2307/1595583.

Mubarok, Achmad. 2016. "Daulah Islamiyah Vs Daulatul Muslimin: Salah Paham Negara Islam.” In Abdul Aziz, Chiefdom Madinah: Kerucut Kekuasaan pada Zaman Awal Islam. Tangerang Selatan: Alvabet.

Muhajir, Afifuddin. 2017. Fiqh Tata Negara: Upaya Mendialogkan Sistem Ketatanegaraan Islam. Yogyakarta: Ircisod.

al-Mujâhid, Sharîf. 1954. "Sayyid Jamâl al-Dîn al-Afghânî: His Role in the Nineteenth Century Muslim Awakening.” Thesis, Mc Gill University.

al-Nabhani, Taqiy al-Din. 2001. Niḍ̂m al-Islâm. n.c: Hizbut Tahrir.

Naeem, Fuad S. 2004. "A Traditional Response to the Rise of Modernism." In Lumbard, Islam, Fundamentalism, and the Betrayal of Tradition. Indiana: World Wisdom.

Najjar, Fauzi M. 1958. "Islam and Modern Democracy." The Review of Politics 20(2): 164-80.

DOI: https://doi.org/10.1017/S0034670500013954.

Noer, Deliar. 2003. Islam Eु Politik. Jakarta: Yayasan Risalah.

Robby, Hadza Min Fadhli. 2020. "Arab Nationalism: Past, Present, and Future." Journal of Integrative International Relations 5(1): 1-32.

DOI: https://doi.org/10.5281/zenodo.4785114.

Rosenthal, E.I.J. 1962. Political Thought in Medieval Islam: an Introductory Outline. London: Cambridge University Press.

Sahal, Akhmad. 2014. "Khilafah: Antara Api Islam dan Abunya." In Kontroversi Khilafah: Islam, Negara, dan Pancasila, ed. Komaruddin Hidayat. Bandung: Mizan.

Sjadzali, Munawir. 1993. Islam dan Tata Negara: Ajaran, Sejarah dan Pemikiran. Jakarta: UI Press.

Suminto, H Aqib. 1985. Politik Islam Hindia Belanda. Jakarta: LP3ES.

Thaba, Abdul Azis. 1996. Islam dan Negara Politik Orde Baru. Jakarta: Gema Insani Press. 
Tibbi, Bassam. 2009. Islam's Predicament with Modernity: Religious Reform and Cultural Change. London \& New York: Routledge.

Toure, Abdoul Karim, Mualimin Mochammad Sahid, Shumsudin Yabi. 2018. "The Concept of Islamic State in the Thought of Rasheed Rida through al Manar: Ottoman Caliphate as Model.” Al-Abqari: Journal of Islamic Social Sciences and Humanities 13(1): 117-29.

Umam, Fawaizul. 2019. "Ideological Involution of the Islamists." Ulul Albab: Jurnal Studi Islam 20(1): 25-42.

DOI: https://doi.org/10.18860/ua.v20i1.5714.

Wahid, Din. 2014. "PhD Thesis Summary: 'Nurturing Salafi Manhaj: A Study of Salafi Pesantren in Contemporary Indonesia." Wacana 15(2): 367-76.

DOI: http://dx.doi.org/10.17510/wacana.v15i2.413.

Washil, Izzuddin dan Ahmad Khoirul Fata. 2018. "Hadis Gadir Khum dalam Pandangan Syiah dan Sunnah.” Al-Dzikra 12(1): 51-74.

DOI: https://doi.org/10.24042/al-dzikra.v12i1.2925.

Watt, W Montgomery. 2003. Islamic Political Thought. Edinburgh: Edinburh University Press.

Zallum, 'Abd al-Qadim. 2002. Nidâm al-Hukm fî al-Islâm. n.c.: Hizb al-Tahrir.

Zallum, 'Abdul Qadim. 1995. Democracy is a System of Kufr: It is Forbidden to Adopt, Implement or Call for It. n.c: al-Khilafah Publication.

Zubaidah, Siti and M. Zulkifli. 2016. "Doctrine and thought of Khawârij and the implication in the present context." IJAER 11(6): 4247-51.

"Demokrasi dan Pemilu." In http://almanhaj.or.id/577- demokrasi- danpemilu. html (Accessed October 12, 2017). 